\title{
PENGARUH PENAMBAHAN ZAT ADITIF TERHADAP KONSUMSI BAHAN BAKAR PADA MOTOR BAKAR BENSIN SUZUKI 4-TAK DOHC (16 HP)
}

\author{
Ismet Eka Putra ${ }^{1}$,Vikky Ilham ${ }^{2}$ \\ Teknik Mesin, Fakultas Teknologi Industri ITP ${ }^{1,2}$ \\ ismetekaputra@ymail.com ${ }^{1}$ \\ DOI: http://dx.doi.org/10.31869/rtj.v2i2.1435
}

\begin{abstract}
Abstrak-Tingkat pemakaian kendaraan bermotor semakin tahun semakin bertambah dan akan menyebabkan tingginya konsumsi bahan bakar. Maka dibutuhkan kendaraan yang memiliki unjuk kerja yang baik dan konsumsi bahan bakar yang minimum. Pemerintah memperkenalkan bahan bakar baru yaitu Pertalite, yang memiliki kualitas bahan bakar yang lebih baik dibandingkan dengan premium. Zat aditif merupakan bahan yang ditambahkan pada bahan bakar kendaraan bermotor yang berguna untuk meningkatkan performance mesin mulai dari durabilitas, akselerasi sampai power mesin. Tujuan dilakukan pengujian ini untuk mengetahui seberapa banyak penggunaan bahan bakar yang terpakai saat pengujian pengereman, seberapa besar pengiritan bahan bakar yang telah di campurkan zat aditif saat terjadi beban pengereman, menganalisa pengurangan bahan bakar yang dicampurkan dengan zat aditif dan tanpa dicampur zat aditif. Sehingga dihasilkan komposisi bahan bakar tanpa mengunakan zat aditif mencapai torsi max 5,488 Joule, daya 2010,4 Watt, dan laju aliran massa $0,000082 \mathrm{~kg} / \mathrm{s}$ dengan kosumsi bahan bakar 0,42 1/jam, Dari pengujian tanpa zat aditif dan mengunakan zat aditif yang paling maximal dengan waktu 120 detik, $7000 \mathrm{rpm}$ dan beban $2 \mathrm{~kg}$, dapat perbandingan berkurangnya pemakaian bahan bakar sebesar 0,06 1/h. Komposisi bahan bakar mengunakan zat aditif mencapai torsi max 5,488 Joule, daya 2010,4 Watt, dan laju aliran massa $0,000071 \mathrm{~kg} / \mathrm{s}$ dengan kosumsi bahan bakar 0,36 1/jam. Pengujian dengan zat aditif sebagai campuran bahan bakar pada komposisi tertentu dapat meningkatkan efesiensi mesin yang memiliki nilai laju aliran massa yang rendah, tetapi sebanding dengan torsi dan daya yang dihasilkan. Bedasarkan pengujian dan analisa yang telah dilakukan, komposisi campuran yang terbaik bagi pertalite adalah $1: 1$.
\end{abstract}

Kata Kunci : motor bakar bensin, bahan bakar, zat aditif, kosumsi bahan bakar.

Abstract-The level of motorized vehicle use is increasing every year and will lead to high fuel consumption. Then a vehicle that has good performance and minimum fuel consumption is needed. The government introduced a new fuel, pertalite, which has better fuel quality than premium. Additive substances are ingredients that are added to motorized fuel which are useful for increasing engine performance ranging from durability, acceleration to engine power. The purpose of this test is to find out how much fuel is used when testing braking, how much fueling has been mixed with additives when braking loads occur, analyzing the reduction of fuel mixed with additives and without additives mixed. So that the resulting fuel composition without using additives reaches max torque 5,488 Joules, power 2010.4 Watts, and mass flow rate $0,000082 \mathrm{~kg} / \mathrm{s}$ with fuel consumption 0,4 l / hr, from substanceless testing additives and using the most maximal additives with a time of 120 seconds, $7000 \mathrm{rpm}$ and a load of $2 \mathrm{~kg}$, a comparison of the reduced use of fuel is $0.06 \mathrm{l} / \mathrm{h}$. The fuel composition using additives reaches max torque 5.488 Joules, power 2010.4 Watts, and mass flow rate $0.000071 \mathrm{~kg} / \mathrm{s}$ with fuel

consumption $0.36 \mathrm{l} / \mathrm{hr}$. Testing with additives as a mixture of fuels in certain compositions can improve engine efficiency which has a low mass flow rate, but is proportional to the torque and power produced. Based on the testing and analysis that has been done, the best mixture composition for pertalite is $1: 1$.

Keywords: motorcycle fuel gasoline, fuel, additive substances, fuel consumption

\section{PENDAHULUAN}

Sepeda motor merupakan alat transportasi yang digerakkan oleh mesin berbahan bakar bensin. Berdasarkan jenis mesin motor yang digunakan sepeda motor dapat digolongkan menjadi dua jenis yaitu, sepeda motor 4 langkah dan sepeda motor 2 langkah. Jenis sepeda motor 2 langkah cukup 
banyak digunakan karena harganya yang relatif murah, biaya perawatannya pun relatif rendah dan mempunyai konstruksi yang sederhana. Namun motor 2 langkah ini mulai ditinggalkan karena boros bahan bakar dibandingkan motor 4 tak. Pemakaian sepeda motor tidak lepas dari jenis bahan bakar yang digunakan. Selama ini kita mengenal bensin (premium), pertamax dan pertamax plus. Bensin adalah cairan campuran yang berasal dari minyak bumi dan sebagian besar tersusun dari hidrokarbon serta digunakan sebagai bahan bakar yang biasa digunakan untuk kendaraan bermotor.

Seiring dengan perkembangan zaman dan semakin berkembangnya ilmu pengetahuan dan teknologi (IPTEK), maka dibutuhkan kendaraan yang memiliki unjuk kerja yang baik dan konsumsi bahan bakar yang minimum. Dengan demikian upaya untuk mendapatkan unjuk kerja mesin yang baik salah satunya dengan memperbaiki kualitas pembakaran yang terjadi di dalam ruang bakar, baik itu motor bensin 4 langkah maupun 2 langkah.

Dalam proses pembakaran pada motor bakar, bahan bakar dan udara tercampur di dalam ruang bakar dan busi digunakan sebagai alat untuk menghasilkan percikan bunga api. Besar kecilnya percikan bunga api busi sangat menentukan kualitas pengapian dan juga pembakaran yang dihasilkan sehingga pengapian dan pembakaran yang optimal dapat meningkatkan kinerja motor yang didukung pula oleh kualitas bahan dan komponen yang digunakan serta waktu pengapian yang tepat pada saat terjadinya proses pembakaran.(Lizasoain, dkk, 2015)

Baru - baru ini pemerintah memperkenalkan produk bahan bakar baru yang yang diberi nama pertalite, bahan bakar ini disebut-sebut akan menggantikan bahan bakar premium. Saat ini harga bahan bakar pertalite masih memiliki harga promo yang begitu murah, sehingga bahan bakar yang dikatakan memiliki kualitas yang lebih baik dari premium ini akan menjadi pesaing bahan bakar pertamax dan pertamax plus. Pertalite merupakan Bahan Bakar Minyak (BBM) jenis baru yang diproduksi Pertamina. Jika dibandingkan dengan premium, pertalite memiliki kualitas bahan bakar yang lebih, sebab memiliki kadar Research Oktan
Number (RON) 90, diatas Premium, yang hanya RON 88. Pertalite memiliki beberapa keunggulan dibandingkan dengan premium. Pertalite direkomendasikan untuk kendaraan yang memiliki kompresi 9:1-10:1 dan kendaraan tahun 2000 ke atas, terutama yang telah menggunakan teknologi setara dengan Electronic Fuel Injection (EFI).(Ariawan, dkk, 2016).

Zat aditif merupakan bahan yang ditambahkan pada bahan bakar kendaraan bermotor, baik mesin bensin maupun mesin diesel. Zat aditif sering disebut juga dengan fuel vitamin. Zat aditif digunakan untuk memberikan peningkatan sifat dasar tertentu yang telah dimilikinya seperti aditif anti detonasi bensin untuk bahan bakar mesin bensin.(Endyani, dkk, 2011)

Manfaat dari Zat Aditif untuk meningkatkan performance mesin mulai dari durabilitas, akselerasi sampai power mesin. Kegunaan lain dari Zat Aditif adalah sebagai berikut:

1. Membersihkan karburator/injector pada saluran bahan bakar.

2. Mengurangi karbon / endapan senyawa organik pada ruang bakar.

3. Menambah tenaga mesin.

4. Mencegah korosi.

5. Menghemat BBM dan mengurangi emisi gas buang.

\section{DASAR TEORI}

Motor bakar adalah salah satu jenis mesin kalor, yaitu mesin yang mengubah energy termal untuk melakukan kerja mekanik atau mengubah tenaga kimia bahan bakar menjadi tenaga mekanis. Sebelum menjadi tenaga mekanis, energi kimia bahan bakar diubah dulu menjadi energi termal atau panas melalui pembakaran bahan bakar dengan udara. Pembakaran ini ada yang dilakukan di dalam mesin kalor itu sendiri dan ada pula yang dilakukan di luar mesin kalor dan siklus otto pada mesin bensin disebut juga dengan siklus volume konstan, dimana pembakaran terjadi pada saat volume konstan.

\section{Klasifikasi Motor Bakar}

Motor bakar dapat diklasifikasikan menjadi 2 macam. Adapun pengklasifikasian motor bakar adalah:

1. Motor pembakaran luar (external combustion engine). 
Mesin pembakaran luar adalah mesin dimana proses pembakaran terjadi di luar mesin itu sendiri. Panas dari bahan bakar itu tidak diubah menjadi tenaga gerak tetapi terlebih dahulu media perantara baru kemudian diubah mejadi tenaga mekanik. Secara umum mesin uap dan turbin memiliki karakter yang hanya dapat dipergunakan sebagai penggerak mula ukuran besar misalnya, lokomotif, kapal, dan power plant dan tidak baik apabila digunakan sebagai penggerak generator serbaguna, sepeda motor dan kendaraan transportasi umum lainnya.

2. Motor pembakaran dalam(internal combustion).

Mesin pembakaran dalam adalah mesin dimana bahan bakarnya terjadi di dalam mesin itu sendiri sehingga panas dari hasil pembakaran langsung bisa diubah menjadi tenaga mekanik. Konstruksi dan perencanaan mesin menjadi lebih kecil dan sederhana, seperti mesin diesel yang dapat beroperasi dalam keadaan suhu tinggi dengan siklus berulang-ulang dan pemanfaatan motor bakar ini telah menyebar luas karena memiliki tenaga yang kuat dan handal disamping itu pemakaian bahan bakar menjadi lebih irit dan efisien.

\section{Langkah kerja Motor Bakar Bensin:}

Proses termodinamika dan kimia yang terjadi dalam motor bakar torak amat kompleks untuk dianalisis menurut teori. Untuk memudahkan analisis tersebut kita dapat mengumpamakan dalam kondisi ideal.
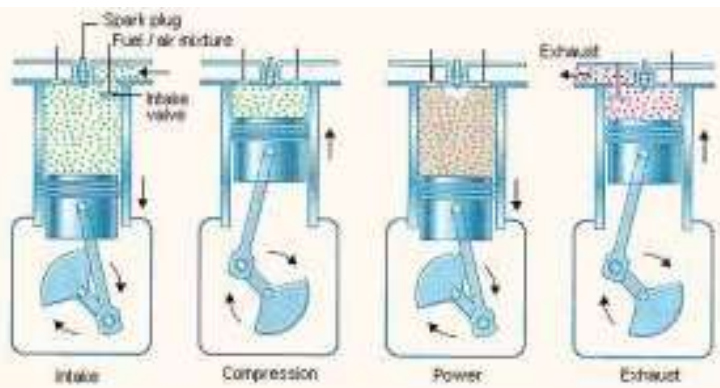

Gambar 1 Langkah Kerja Motor Bakar Bensin (TMA ke TMB)

Langkah Pertama: Piston bergerak dari TMA ke TMB, posisi katup masuk terbuka dan katup keluar tertutup, mengakibatkan udara (mesin diesel) atau gas (sebagian besar mesin bensin) terhisap masuk ke dalam ruang bakar. Proses udara atau gas sebelum masuk ke ruang bakar dapat dilihat pada katub hisap.

Langkah ke dua: Piston bergerak dari TMB ke TMA, posisi katup masuk dan keluar tertutup, mengakibatkan udara atau gas dalam ruang bakar terkompresi. Beberapa saat sebelum piston sampai pada posisi TMA, waktu penyalaan (timing ignition) terjadi (pada mesin bensin berupa nyala busi sedangkan pada mesin diesel berupa semprotan (suntikan) bahan bakar).

Langkah ketiga: Gas yang terbakar dalam ruang bakar akan meningkatkan tekanan dalam ruang bakar, mengakibatkan piston terdorong dari TMA ke TMB. Langkah ini adalah proses yang akan menghasilkan tenaga.

Langkah ke empat: Piston bergerak dari TMB ke TMA, posisi katup masuk tertutup dan katup keluar terbuka, mendorong sisa gas pembakaran menuju ke katup keluar yang sedang terbuka untuk diteruskan ke katub pembuangan.

Persamaan :

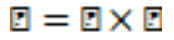

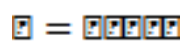

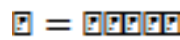

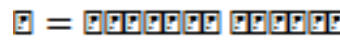

$$
\begin{aligned}
& \nabla=\left(\frac{2 \times \mathbb{G} \times \mathbb{G}}{\square}\right) \times \mathbb{\square}
\end{aligned}
$$

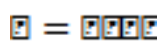

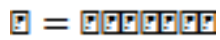

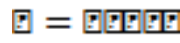

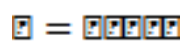

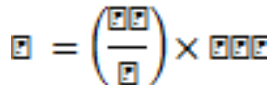

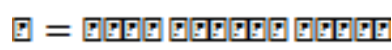

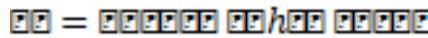

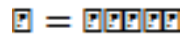

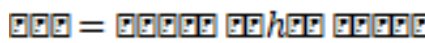

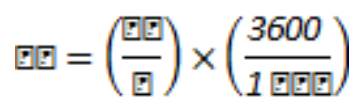

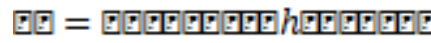

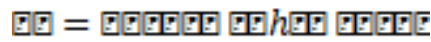

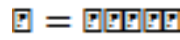


Siklus Otto adalah siklus thermodinamika yang paling banyak digunakan dalam kehidupan manusia. Mobil dan sepeda motor berbahan bakar bensin (Petrol Fuel) adalah contoh penerapan dari sebuah siklus Otto. Secara thermodinamika, siklus ini memiliki 4 buah proses thermodinamika yang terdiri dari 2 buah proses isokhorik (volume tetap) dan 2 buah proses adiabatis (kalor tetap). Untuk lebih jelasnya dapat dilihat diagram $p$ vs $v$ berikut:

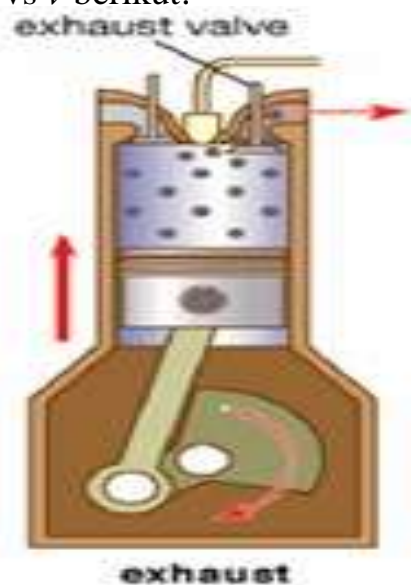

Gambar 2 Siklus Otto

Proses yang terjadi adalah :

1-2: Kompresi adiabatic

2-3 : Pembakaran isokhorik

3-4 : Ekspansi / langkah kerja adiabatic

4-1 : Langkah buang isokhori

\section{METODOLOGI PENELITIAN}

Flowchart Penelitian

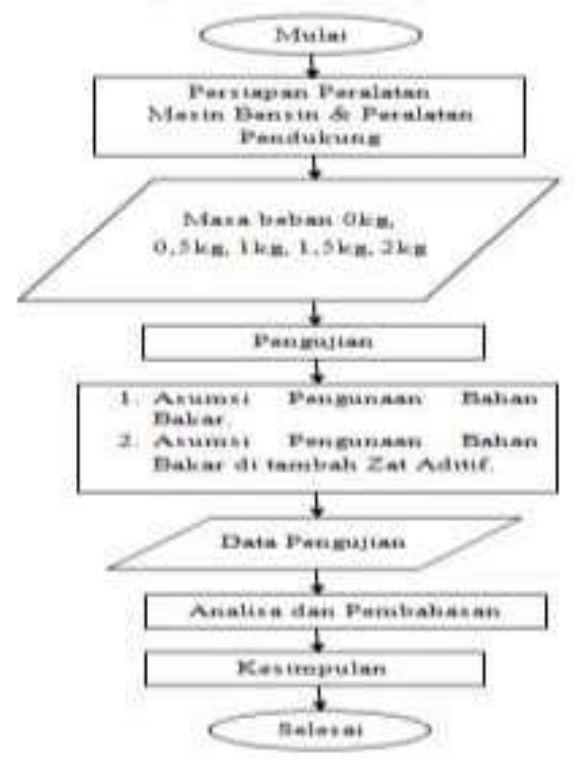

Skema Alur Pengujian

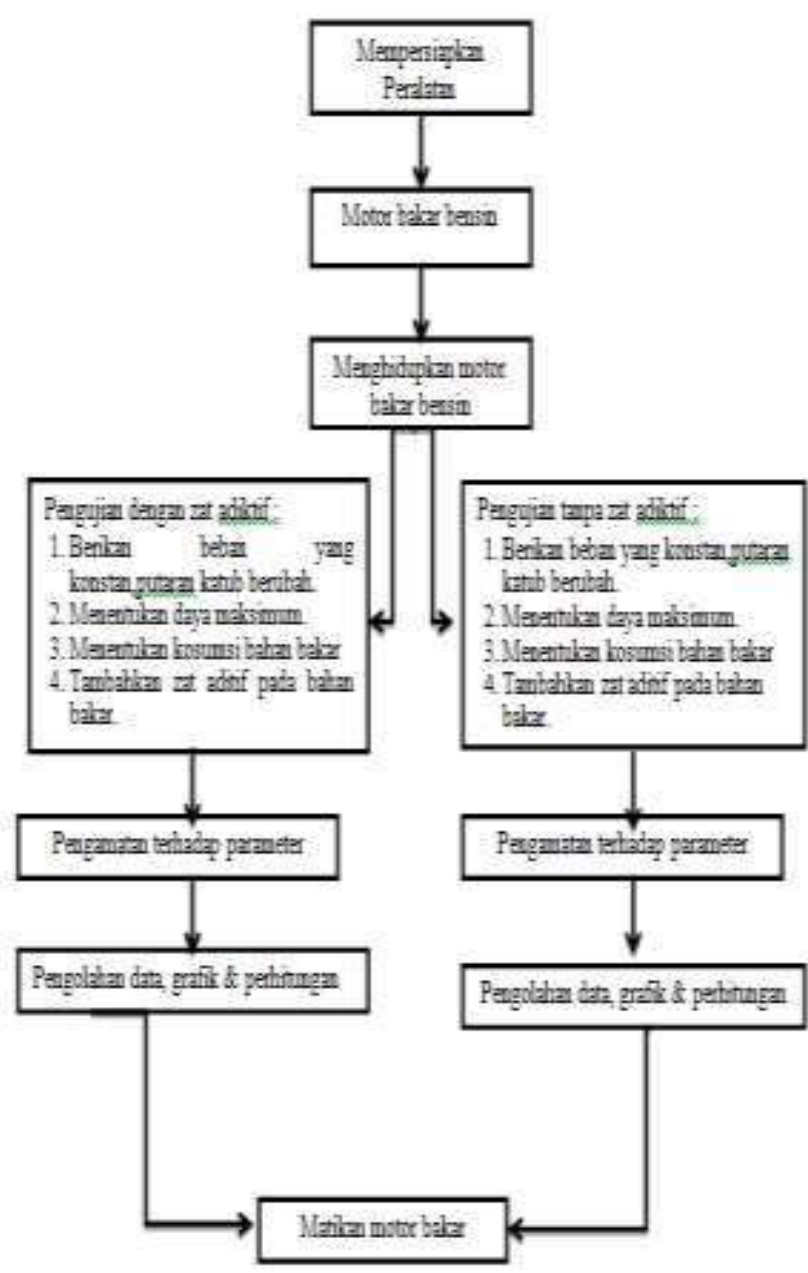

Bahan dan Alat Penelitian

a. Motor Bakar Bensin

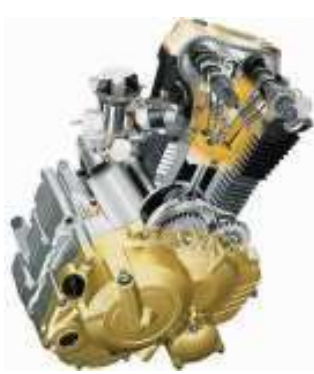

Gambar 3 Motor Bakar bensin Suzuki 4tak DOHC 
b. Thermoguns

Digunakan untuk mengukur panas pada pipa gas buang

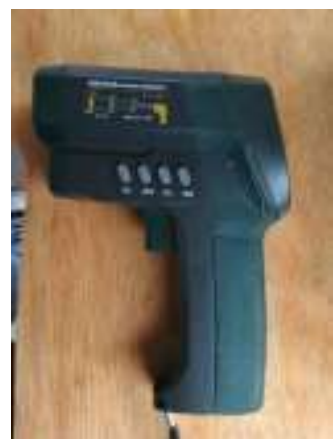

Gambar 4 Thermoguns

c. Tachometer

Digunakan untuk mengukur putaran.

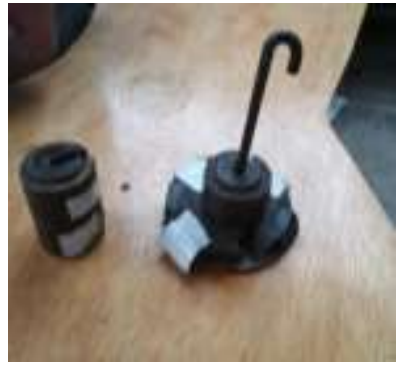

Gambar 5 Tachometer

d. Stopwatch

Digunakan untuk mengukur waktu selama pengujian berlangsung.

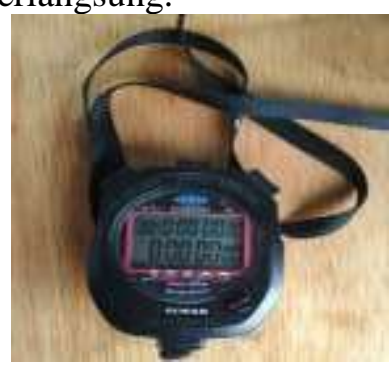

Gambar 6 Stopwatch e. Beban

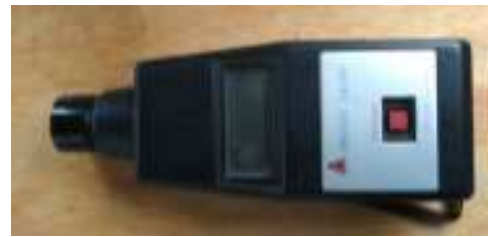

Gambar 7 Beban

f. Bahan Bakar

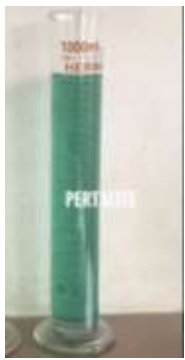

Gambar 8 Bahan Bakar

g. Zat Aditif

Kandungan sinergi zat aditif :

- Detergent Chemical Organic Function yg berfungsi untuk meyempurnakan pembakaran dan mempertahankan mesin tetap stabil performa.

- Corrosion Inhibitor. Dapat mencegah korosi/karat pada saluran bensin dan mesin pembakaran, serta membuang sisa karat karena penggunaan bbm yang salah seperti premium pada motor dengan kompresi diatas 9:1 (jenis injection dan matic).

- De Emulsion. Dapat memisahkan zat murni bahan bakar dengan emulsi pengotor seperti air hujan dll. Sehingga tak berpengaruh pada proses pembakaran

\section{Prosedur Pengujian}

1. Mempersiapkan semua peralatan

- Mesin Motor Bakar Bensin

- Thermoguns

- Tachometer

- Stopwatch

- Beban

- Bahan Bakar

- Zat Aditif

- Tabel Data 
2. Menghidupkan Mesin Motor Bakar Bensin

- On (aktif) stop kontak pada mesin.

- Buka katup bahan bakar dan buka katup gas pada posisi rendah.

- Putar poros engkol pada beberapa putaran denganme ngunakan engko lengan,setelah mesin menyala lepaskan tuas engkol dan letakkan ketempat semula berada.

3. Pengujian

Pengujian dilakukan setelah mesin menyala dan beroperasi normal 10-15 menit untuk :

- Berikan beban yang konstan,putaran katub berubah.

- Menentukan daya maksimum.

- Menentukan kosumsi bahan bakar

- Tambahkan zat aditifpada bahan bakar.

4. Untuk beberapa kondisi operasimesin dilakukan pengamatan terhadap parameterparameter diatas.

5. Data pada pengujian asumsi pemakaian bahan bakar yang belum di campur zat aditif diolah dan di buat grafik beserta analisa, perhitungan terhadap pengujian-pengujian tersebut.

6. Lakukan langkah-langkah pengujian yang sama seperti pengujian sebelumnya.

7. Data pada pengujian asumsi pemakaian bahan bakar yang telah ditambahkan zat aditif di olah dan dibuat grafik beserta analisa, perhitunggan terhadap pengujianpengujiantersebut.

8. Setelah menyelesaikan pengambilan data, maka matikan mesin.

\section{HASIL DAN PEMBAHASAN}

Data Hasil Pengujian

Tabel 1 Data Pengujian Tanpa Zat Aditif.

\begin{tabular}{|c|c|c|c|c|c|c|}
\hline $\begin{array}{l}\mathrm{N} \\
\mathrm{o}\end{array}$ & $\begin{array}{c}\text { Puta } \\
\text { ran } \\
\text { (rp } \\
\text { m) }\end{array}$ & $\begin{array}{c}\text { Vol- } \\
\text { Baha } \\
\text { n } \\
\text { Baka } \\
\text { r (ml) }\end{array}$ & $\begin{array}{c}\text { Panjan } \\
\text { g } \\
\text { Lenga } \\
\mathrm{n} \\
(\mathrm{m})\end{array}$ & $\begin{array}{c}\text { Tem } \\
\text { p } \\
\text { Gas } \\
\text { Buan } \\
\text { g } \\
\left({ }^{\circ} \mathrm{C}\right)\end{array}$ & $\begin{array}{l}\text { Wa } \\
\text { k-tu } \\
\text { Pen } \\
\text { guji } \\
\text { an } \\
(S)\end{array}$ & $\begin{array}{c}\text { Massa } \\
\text { Beban } \\
(\mathrm{Kg})\end{array}$ \\
\hline 1 & $\begin{array}{c}3.00 \\
0\end{array}$ & 0,7 & 0,28 & 47,8 & 120 & 0 \\
\hline 2 & 4.00 & 10 & 0,28 & 67,3 & 120 & 0,5 \\
\hline
\end{tabular}

\begin{tabular}{|c|c|c|c|c|c|c|}
\hline & 0 & & & & & \\
\hline 3 & $\begin{array}{c}5.00 \\
0\end{array}$ & 12 & 0,28 & $\begin{array}{c}112, \\
1\end{array}$ & 120 & 1 \\
\hline 4 & $\begin{array}{c}6.00 \\
0\end{array}$ & 13 & 0,28 & $\begin{array}{c}138, \\
7\end{array}$ & 120 & 1,5 \\
\hline 5 & $\begin{array}{c}7.00 \\
0\end{array}$ & 14 & 0,28 & $\begin{array}{c}164, \\
2\end{array}$ & 120 & 2 \\
\hline
\end{tabular}

Tabel 2 Data Pengujian Mengunakan Zat Aditif

\begin{tabular}{|c|c|c|c|c|c|c|}
\hline $\begin{array}{c}\mathrm{N} \\
\mathrm{o}\end{array}$ & $\begin{array}{c}\text { Putar } \\
\text { an } \\
(\mathrm{rpm})\end{array}$ & $\begin{array}{c}\text { Vol- } \\
\text { Baha } \\
\mathrm{nBak} \\
\text { ar } \\
(\mathrm{ml})\end{array}$ & $\begin{array}{c}\text { Panjan } \\
\mathrm{g} \\
\text { Lenga } \\
\mathrm{n}(\mathrm{m})\end{array}$ & $\begin{array}{c}\text { Temp } \\
\text { Gas } \\
\text { Buang } \\
\left({ }^{\circ} \mathrm{C}\right)\end{array}$ & $\begin{array}{c}\text { Wa } \\
\text { k-tu } \\
\text { Pen } \\
\text { guji } \\
\text { an } \\
(\mathrm{S})\end{array}$ & $\begin{array}{c}\text { Mass } \\
\mathrm{a} \\
\text { Beba } \\
\mathrm{n} \\
(\mathrm{Kg})\end{array}$ \\
\hline 1 & 3.000 & 0,6 & 0,28 & 57,1 & 120 & 0 \\
\hline 2 & 4.000 & 0,8 & 0,28 & 76,5 & 120 & 0,5 \\
\hline 3 & 5.000 & 0,9 & 0,28 & 115,8 & 120 & 1 \\
\hline 4 & 6.000 & 10 & 0,28 & 147,2 & 120 & 1,5 \\
\hline 5 & 7.000 & 12 & 0,28 & 171,1 & 120 & 2 \\
\hline
\end{tabular}

\section{Hasil Perhitungan Data dan Pembahasan}

Tabel 3 Tabel Data Hasil Perhitungan Tanpa Zat

Aditif

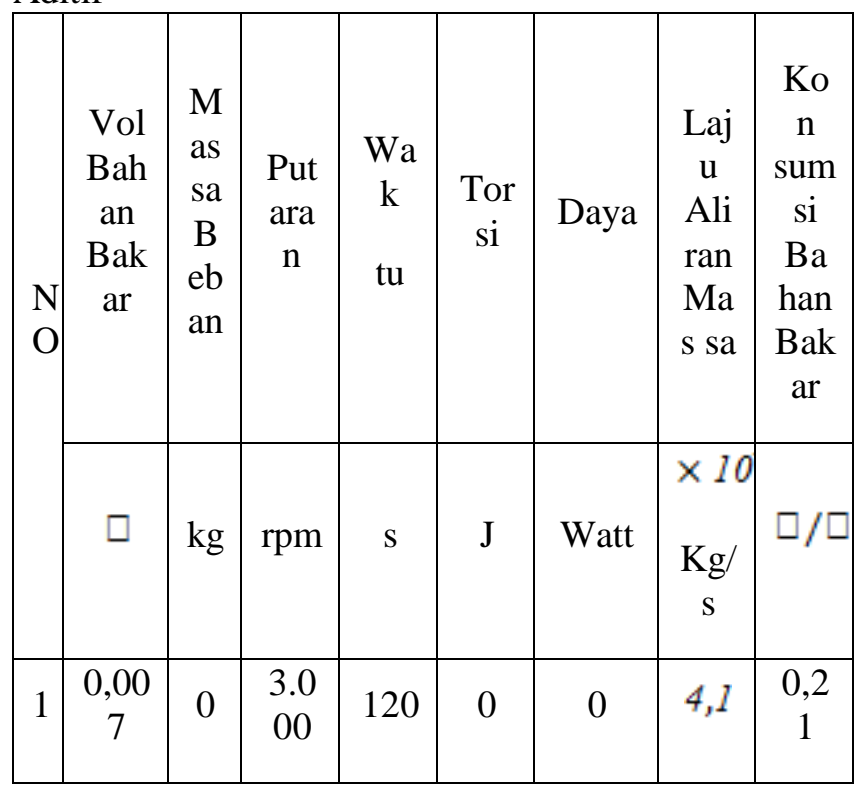


Vol. 2 No.2 Juni 2019

http://jurnal.umsb.ac.id/index.php/RANGTEKNIKJOURNAL

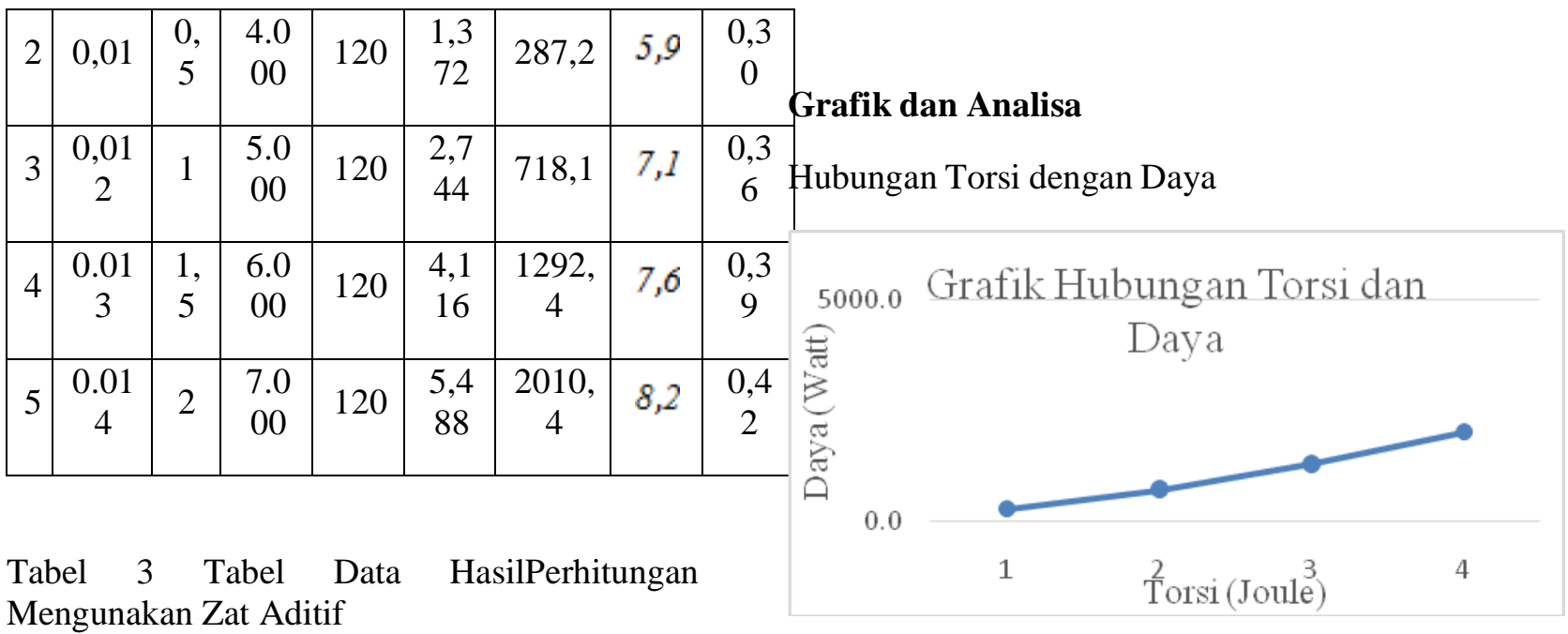

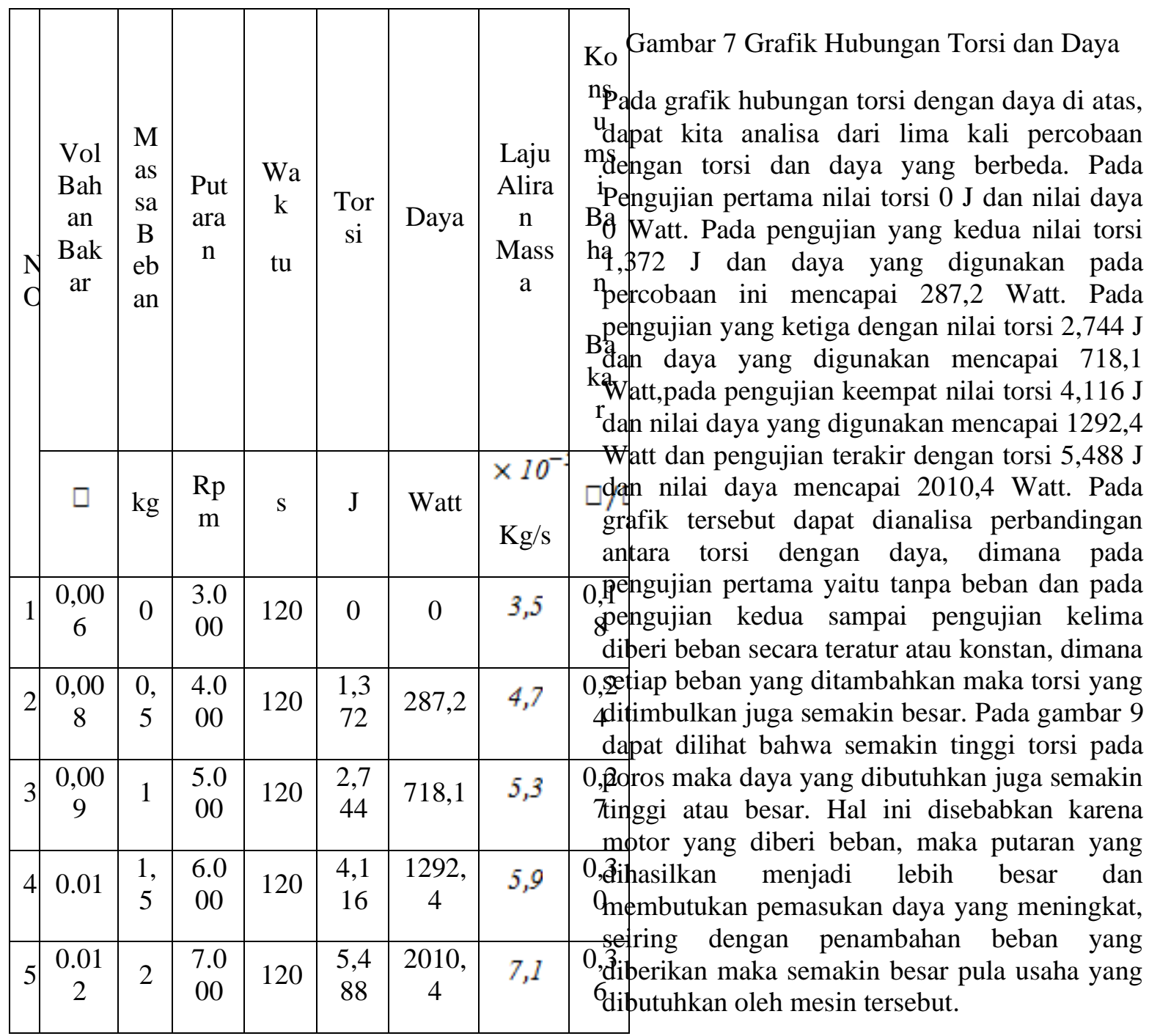


Hubungan Laju Aliran Massa Dan Daya

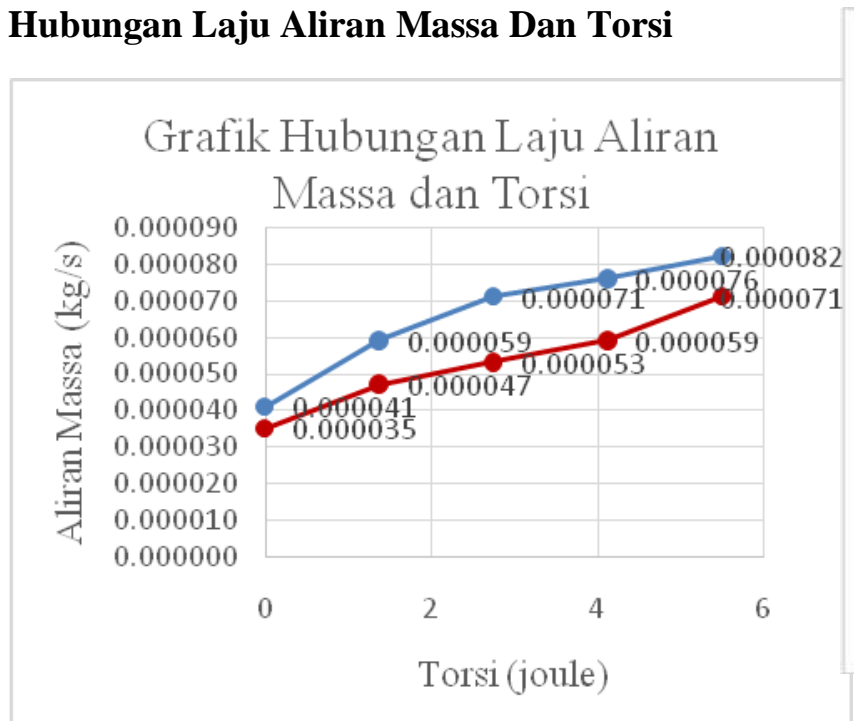

Gambar 8 Grafik Hubungan Laju Aliran Massa dan Torsi

Dari Gambar 8 diatas dapat dilihat perbandingan antara laju aliran massa bahan bakar dan torsi. Diketahui perbandingan torsi pada poros mempengaruhi pemakaian bahan bakar. Pada pengujian pertaman sampai pengujiaan kelima tanpa mengunakam zat aditif didapatkan laju aliran massa dengan nilai $0,000041,0,000059,0,000071,0,000076$, $0,000082(\mathrm{~kg} / \mathrm{s})$. Sedangkan pengujian pertama sampai kelima dengan mengunakan zat aditif didapatkan laju aliran massa dengan nilai $0,000035,0,000047,0,000053,0,000059$, $0,000071(\mathrm{~kg} / \mathrm{s})$. Dua pengujian tersebut sama mengunakan torsi yang sama dari pengujian pertama sampai pengujian kelima yaitu 0 , $1,371,2,744,4,116,5,488(\mathrm{~J})$. Dari data tersebut bahwa laju aliran massa pada pengujian dengan menggunakan zat aditif lebih rendah nilainya dari pengujiantanpa menggunakan zat aditif. Hal ini dipengaruhi oleh kenaikan torsi sehingga kosumsi bahan bakar meningkat, akibat laju aliran massa yang meningkat untuk kenaikan torsi. Sehingga pada pengujian dengan mengunakan zat aditif terlihat laju aliran massa lebih rendah dari pengujian tanpa zat aditif. Hal inilah yang mempengaruhi kosumsi bahan bakar.

\section{Grafik Hubungan Laju Aliran} Massa Dan Daya

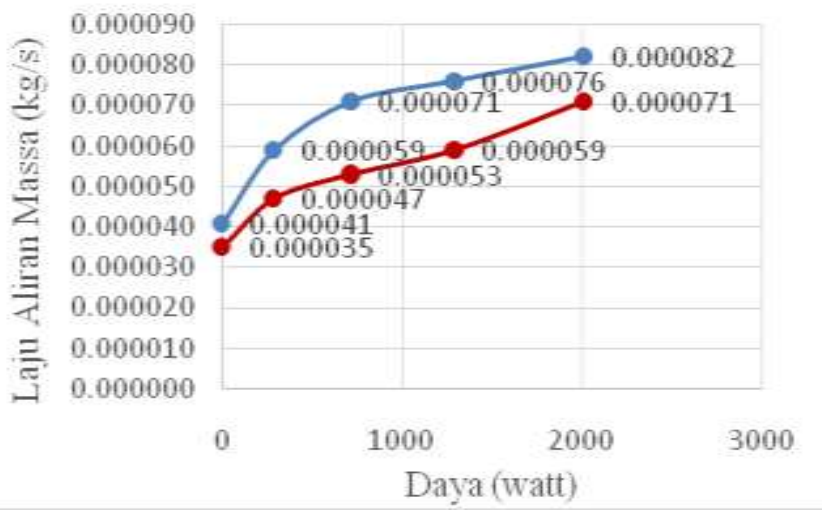

Gambar 9 Grafik Hubungan Laju Aliran Massa dan Daya

Dari Gambar 9 diatas dapat dilihat perbandingan antara laju aliran massa bahan bakar dan daya. Diketahui perbandingan daya dan poros mempengaruhi pemakaian bahan bakar,untuk menghasilkan daya pada mesim diperlukan bahan bakar yangmeningkat setiap penambahan beban dan daya yang dihasilkan juga meningkat, Pada pengujian pertaman sampai pengujiaan kelima tanpa mengunakam zat aditif mengalami peningkatan laju aliran massa dengan nilai $0,000041,0,000059$, $0,000071,0,000076,0,000082(\mathrm{~kg} / \mathrm{s})$. Sedangkan pengujian pertama sampai kelima dengan mengunakan zat aditif mengalami penurunan pada asumsi laju aliran massa dengan nilai $0,000035,0,000047,0,000053$, $0,000059,0,000071(\mathrm{~kg} / \mathrm{s})$. Dimana dua pengujian tersebut mengunakan torsi yang sama dari pengujian pertama sampai pengujian kelima yaitu 0 , 287,2 , 718,1 , 1292,4 , 2010,4(Watt).Dari data tersebut bahwa laju aliran massa pada pengujian dengan menggunakan zat aditif lebih rendah nilainya dari pengujian tanpa menggunakan zat aditif. Hal ini dipengaruhi oleh kenaikan daya sehingga kosumsi bahan bakar meningkat, akibat laju aliran massa yang meningkat untuk kenaikan daya. Sehingga pada pengujian dengan mengunakan zat aditif terlihat laju aliran massa lebih rendah dari pengujian tanpa zat aditif. Hal inilah yang mempengaruhi kosumsi bahan bakar. 
penambahan zat aditif pada bahan bakar

Hubungan Fuel Comsumtion dan Daya

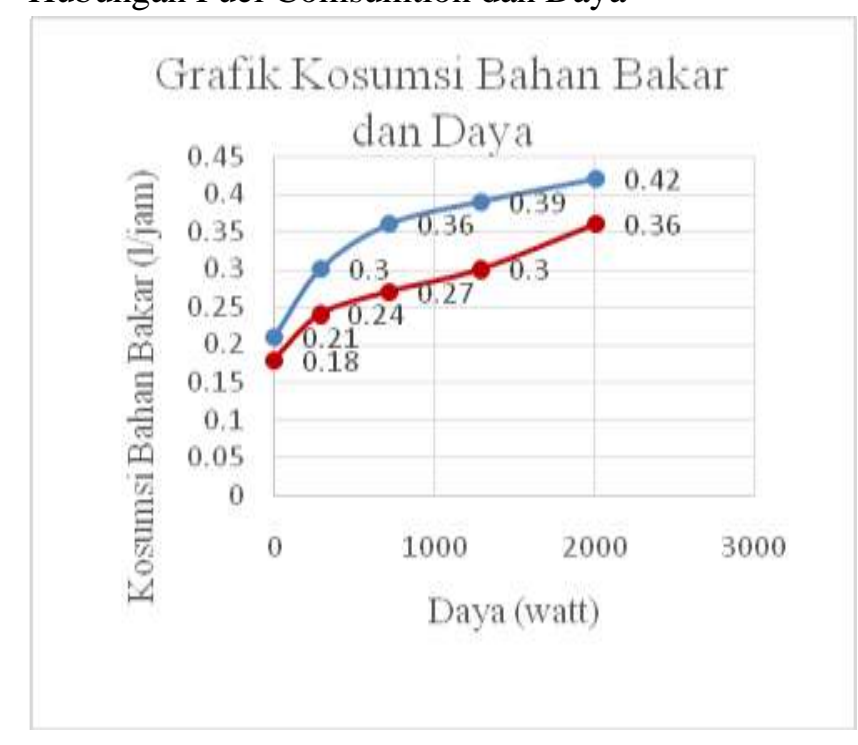

Gambar 10 Grafik Kosumsi Bahan Bakar dan Daya

Dari Gambar 10 diatas dapat dilihat perbandingan Fuel Comsumtion dan Daya.Sehingga dapat diketahui pemakaian bahan bakar setiap waktu untuk menghasilkan daya.Pada pengujian tersebut dapat dianalisa bahwa setiap daya yang dihasilkan membuat kosumsi bahan bakar juga meningkat.Jadi peningkatan kosumsi bahan bakar setiap waktu mesin beroperasi untuk menghasilkan daya yang lebih besar. Pada pengejian tanpa mengunakan zat aditif dapat kita lihat pemakaian bahan bakar yaitu $0,21,0,30,0,36$, $0,39,0,42(\mathbb{\nabla} / \mathbb{\Xi})$. Sedangkan pada pengujian mengunakan zat aditif pada bahan bakar berdampak mengurangi asumsi bahan bakar dari pengujian sebelumnya dengan nilai 0,18 , $0,24,0,27,0,30,0,36($ 四/四 $)$. Daya yang digunakan 0 , 287,2 , 718,1 , 1292,4 , 2010,4 (Watt). Pada pengujian mengunakan zat aditif mengalami penurunan pemakaian bahan bakar sekitar 0,06 (四/四) di sebabkan penambhan zat aditif tersebut meningkankan 5 RON. Sehingga RON bahan bakar yang digunakan meningkat dan mengoptimalkan proses pembakaran pada mesin dan membuat pemakaian bahan bakar lebih minim.

\section{PENUTUP}

Dari hasil penelitian dan analisa yang dilakukan bedasarkan pengujian pengaruh pertalite :

1. Komposisi bahan bakar tanpa mengunakan zat aditif mencapai torsi max: 5,488 Joule, daya: 2010,4 Watt, Laju aliran massa: $0,000082 \mathrm{~kg} / \mathrm{s}$ dengan fuel comsumtion: 0,42 1/h.

2. Komposisi bahan bakar mengunakan zat aditif mencapai torsi max: 5,488 Joule, daya: 2010,4 Watt, Laju aliran massa: $0,000071 \mathrm{~kg} / \mathrm{s}$ dengan fuel comsumtion: $0,36 \mathrm{l} / \mathrm{h}$.

3. Dari pengujian tanpa zat adiftif dan mengunakan zat aditif yang paling maximal dengan waktu 120 detik, $7000 \mathrm{rpm}$ dan beban $2 \mathrm{~kg}$, dapat perbandingan berkurannya pemakaian bahan bakar sebesar 0,06 1/h.

4. Penggunaan zat aditif sebagai campuran bahan bakar pada komposisi tertentu dapat meningkatkan efesiensi mesin. Walaupun memiliki nilai laju aliran massa yang rendah, tetapi sebanding dengan torsi dan daya yang dihasilkan.

\section{DAFTAR PUSTAKA}

Ariawan, IWB, Kusuma, IGBW, \& Adnyana, IWB (2016). Pengaruh Penggunaan Bahan Bakar Pertalite Terhadap Unjuk Kerja Daya, Torsi Dan Konsumsi Bahan Bakar Pada Sepeda Motor Bertransmisi Otomatis. 2(1), 51-58.

DEndyani, TDPutra. (2011). Pengaruh Penambahan

Zat Aditif Pada Bahan Bakar. Proton, 3(1), 2934.

Ningrat, AAWK, Kusuma, IGBW \& Adnyana, IWB (2016).Pengaruh Penggunaan Bahan Bakar Pertalite Terhadap Akselerasi Dan Emisi Gas Buang Pada Sepeda Motor Bertransmisi Otomatis, 2(1), 59-67.

Samsiana, S \& Sikki, MI (2014). Analisis Pengaruh Bentuk Permukaan Piston Model Kontur Radius Gelombang Sinus Terhadap Kinerja Motor Bensin. Jurnal Imiah Teknik Mesin, Universitas Islam 45, Bekasi, 2(1), 43-49.

Suyatno, A. (2010). Pengaruh Pemanasan Bahan Bakar Dengan Radiator Sebagai Upaya Meningkatkan Kinerja Mesin Bensin. 2(2), 23-27. 